\title{
GOTTSCHEER FOLK SONG - FROM A MEANS OF FOSTERING NATIONAL DIFFERENTIATION TO A MEMORY KEEPER IN THE DIASPORA
}

\section{ANJA MORIC}

The article focuses on changes in the roles and uses of Gottscheer folk song from the mid-nineteenth century to the present day. The first part addresses how nationalist activists used folk songs from the end of the nineteenth century to $1941 / 42$ in order to instill the idea of a national identity in the Kocevje region. The second part offers insight into the role offolk song in preserving the identity of present-day Gottscheers in the diaspora. The paper also touches on the concept of "German linguistic islands" and points to the role of scholarship in the (mis)understanding of the multicultural reality of linguistically mixed regions.

Keywords: Gottschee, Gottscheers, Gottschee Germans, folk song, nationalism, multilingual regions, linguistic islands, national identity
Članek prikaže spremembe v vlogi in rabi kočevarske ljudske pesmi od srede 19. stoletja do danes. Vprvem delu odgovarja na vprašanje, kako so nacionalistični aktivisti od konca 19. stoletja do leta 1941/42 uporabljali ljudske pesmi, da biv lokalno okolje Kočevske vsadili idejo nacionalne identitete. $V$ drugem delu pa prinaša nova spoznanja o vlogi pesmi za ohranjanje identitete današnjih Kočevarjev v diaspori. Prispevek se dotakne tudi koncepta "nemških jezikovnih otokov" in vloge znanosti pri (ne) razumevanju večkulturne realnosti mešanih jezikovnih območij.

Ključne besede: Kočevska, Kočevarji, kočevski Nemci, ljudska pesem, nacionalizem, večjezična območja, jezikovni otoki, narodna identiteta

In the Kočevje (Germ. Gottschee) region ${ }^{1}$ in southeastern Slovenia two cultures-Slovenian and German - coexisted for centuries; that is, until the emergence of Nazism in the 1930s and the resulting resettlement of the Gottscheers (i.e., Gottschee Germans) in 1941/42. During the rise of nationalistic fervor in the second half of the nineteenth century, the local identification "Gottscheer" (i.e., inhabitants of the Kočevje region) became tinged by imposed nationalism, and gradually the division into Gottschee Germans or Gottschee Slovenians began to take hold. The relationship between the two groups was marked by a nationalistic search for differences between them, which influenced their perception of their (shared) cultural heritage. The heritage of a multi-ethnic environment thus became a tool with which nationalist activists sought to arouse national emotions within a nationally undefined population.

The situation was similar in other linguistically mixed regions of Austria-Hungary, where nationalist activists strived to promote their preferred linguistic group using different (but related) ways to emphasize cultural differences (Judson 2018: 289-290). These included ethnographic studies and collecting folklore material, population censuses, establishing schools and nationalist associations, press involvement, and so on. In addition, folk songs became "a means of enhancing feelings of national identity" (Sweers 2005: 68).

1 The mixed linguistic area of Kočevje measured about 800 square kilometers. For the geographical definition see Ferenc 2005: 17-28. 
This article focuses on the use of Gottscheer folk songs in identity-creation processes among the Gottscheers in different socio-political contexts from the mid-nineteenth century to the present day. The aim is to both a) clarify the process of national identity creation in the Kočevje area, which-in spite of numerous historical studies - has not yet been researched, and b) provide new insight into the current situation of Gottscheers in the diaspora.

In the first part, this case study focuses on the role of Gottscheer folk song in the national differentiation processes in the Kočevje area at the end of the nineteenth and early twentieth centuries, when the view of the Gottscheer identity as German, instead of local or regional (tied to the Kočevje area), was established. Changed (self-)identifications in line with changes in political conditions during various periods of time are also reflected in the adaptations and interpretations of the Gottscheer folk songs at those times. Based on an analysis of the Gottscheer folk song collections (Hauffen 1895; Meier 1930; Brednich and Suppan 1969, 1972, 1984; Gottscheer Chore 1980), newspapers (Gottscheer Bote [1904-1919]; Gottscheer Kalender [1921-1941]; Gottscheer Zeitung [1919-1941]) and archival sources from the Archdiocesan Archives of Ljubljana and the Institute of Ethnomusicology ZRC SAZU archive, the article offers a critical reflection on how nationalist activists used folk songs to instill ideas about national identity in the local environment of the Kočevje region. In the second part, the article offers a look at the current situation. Based on the author's extensive study The Maintenance of the Gottscheer Identity (MGI), ${ }^{2}$ conducted among Gottscheers living in the US, Canada, Austria, Germany, and Slovenia, it presents the significance of Gottscheer folk songs for the identifications of present-day Gottscheers in the diaspora. It shows that the role of folk song also changed within the new social reality in which emigrants found themselves after the Second World War. Its specific new task is to preserve the memory of the old homeland as well as the disappearing Gottscheer dialect. At the same time, the article touches on forgotten intercultural contacts and coexistence in the Kočevje region before the Second World War, which is still reflected in singing and music. The paper also questions the concept of "German linguistic islands" and points to the role of scholarship in the (mis) understanding of the multicultural reality of the mixed linguistic regions.

2 The research project The Maintenance of the Gottscheer Identity, which I conducted among Gottscheers living in the US, Canada, Austria, Germany, and Slovenia between 2007 and 2015, utilized a combination of quantitative and qualitative research methods. I used a sequential explanatory design method (Lobe 2006: 66). I began the study by collecting and analyzing quantitative data (a survey questionnaire with 166 Gottscheer respondents from Slovenia, Austria, Germany, Canada, and the US), which was followed by the collection and analysis of qualitative data, whereby I applied a multisited ethnography research method (Marcus 1995: 106-110; Falzon 2009: 2) due to the worldwide dislocated settlement of Gottscheers. I collected 62 life stories and reflections of Gottscheers from the countries mentioned above, attended at least ten events held by Gottscheer associations in Slovenia, Austria, and the US, and visited several Gottscheer associations and individuals all over the world. Although the MGI research is now finished, I continue to collect information and keep in touch with Gottscheers from all over the world. 


\section{A BRIEF (HISTORICAL) INTRODUCTION}

In the past, the Kočevje area was known as a "German linguistic island" (Germ. Deutsche Sprachinsel). On its own, this term, which became popular in the mid-nineteenth century, defined the Germanness of the area. However, it did not take into account multilingualism or the mutual exchange of cultural elements, which, as discussed below, was the actual situation. This was reflected in everyday life, through various cultural practices in similar forms present in both Slovenian and Gottscheer communities, and also Gottscheer folk songs (see Kumer 1987; Stanonik 2004).

In fact, the Counts of Ortenburg, who began to populate their sparsely inhabited estates in the Kočevje region in the 1330s, deserve credit for opening up the opportunity for the exchange of cultural elements and various modes of coexistence that developed in the Kočevje area. Linguists that have studied the Gottschee dialect determined that the majority of colonists originated from the Ortenburg estates in upper Carinthia and eastern Tyrol (the Puster and Lesach valleys; Petschauer 1984: 87). However, according to the writings of Tomaž Hren, the Bishop of Ljubljana (consecrated in 1599), 300 rebellious families from Frankonia and Thuringia were also sent to Kočevje after the initial stages of colonization (Grothe 1931: 33). Other immigrants came from other Slovenian-speaking regions: Stari Trg, Lož, Cerknica, and Idrija ${ }^{3}$ in Carniola (Petschauer 1984: 87-88), and Carinthia (Ferenc 2005: 31). Although there are no reliable sources on the actual origins of the colonists, it is known that colonization was a long-lasting process that took place until the end of the fourteenth century. It was carried out due to economic reasons; that is, in order to expand the taxable productive land of the district. ${ }^{4}$

In the Kočevje region, therefore, an interesting mixed linguistic area developed. Use of Gottscheerish (known locally as Göttscheabarisch), a dialect that preserved elements of medieval German and at the same time internalized some elements of Slovenian, prevailed. The denomination "Gottscheer" (Eng. and Germ. Gottscheer; local dialect Gottscheabar; Slovenian Kočevar) became an appellation for an inhabitant of that land. As elsewhere across Slovenia (e.g., Drnovšek 2005; Čuček and Cvirn 2012: 30), it was typical that before the rise of nationalism in the middle of nineteenth century such local denominations were neutral and did not denote the inhabitants' ethnic origin. Language was also not an indicator of ethnicity (Judson 2006; Kosi 2010; Almasy and Tropper 2018: 11-13), but rather a way of distinguishing between cultural communities (Hobsbawm 2007: 73). National differentiation was fostered with the arrival of foreign German-speaking intellectuals and bureaucrats, who were seeking supposedly ancient elements of Germanness in the Kočevje area. They began framing it as a "linguistic island," which pushed the area's multiculturalism

3 They settled in the Draga (Germ. Suchen) Valley in the western part of the Kočevje area (Petschauer 1984: 87-88).

4 A larger number of settlers meant more revenue for the landlord. 
or multilingualism into oblivion and started accentuating its Germanness. Thus, Kočevje region was taken up by the "nationalist cause," or at least a push for sharper differentiations between Slovenians and Germans. ${ }^{5}$

The First World War brought about new political circumstances and changed the Gottscheers' status. They became a minority ${ }^{6}$ in the newly-formed Yugoslav state. Although at the end of the nineteenth century some parents from Gottscheerish-speaking villages were sending their children to the more distant Slovenian schools so that they would learn various languages (e.g., Trdan 1999: 62), the contradictions (especially the linguistic ones) during the interwar period already started to reflect in public and in religious life. The conflict escalated with the spread of Nazism and with the resettlement of the Gottscheers to eastern Slovenia (in the vicinity of Brežice [Germ. Rann], then under German rule) in 1941-42 on the basis of an agreement between Hitler and Mussolini. ${ }^{7}$ The Slovenian population living there had been deported and sent to labor camps and the Gottscheers were settled in their emptied homes. After the war, the Gottscheers fled from the resettlement region. Those that were unable to cross the border to Austria were deported, incarcerated in camps, or executed. After the war, they made new homes for themselves in Austria, Germany, the US, and Canada. Before resettlement in 1940, 12,498 Gottscheers were living in the Kočevje region (Ferenc and Repe 2004: 148). After the war, fewer than 600 remained in Slovenia (Ferenc 2005: 269).

During the 1950s, new immigrants from other parts of Slovenia came to this nearly vacant region and the remaining Gottscheers assimilated with the majority population, for

5 For a better understanding of how the linguistic frontiers and national borderlands in Austria-Hungary were created, see Judson 2006.

6 With the peace treaty concluded with Austria on October 10th, 1919 in Saint Germaine, the Kingdom of Serbs, Croats and Slovenes (SCS) provided minimal minority protection to the German minority living within its territory. It committed to protect minorities that differed from the majority population in terms of race, religious beliefs, or language. Austria adopted similar commitments regarding its minorities (Cvirn 2002a: 114). The Kingdom of SCS, Poland, Romania, Greece, and Czechoslovakia signed a special peace treaty with the allied forces regarding the protection of national minorities. However, this treaty provided only personal protection rights to minorities living in the Kingdom of SCS and not group rights. Articles 8 and 9 of said treaty pertained directly to minorities and allowed them to establish and manage (at their own expense) charitable, religious, and social institutions, and schools and other educational institutions where they could "freely use their language and practice their religion" (Komac and Zagorac 2002: 142). However, the Minorities Protection Treaty was not incorporated into the Vidovdan Constitution of 1921 or into the imposed constitution of 1931, irrespective of the fact that the Kingdom of SCS pledged to recognize the articles from said treaty as basic laws. Article 16 of the Vidovdan Constitution was the only article that provided the right to schooling in one's native language under the conditions stipulated by law (Cvirn 2002b: 116).

7 In 1941, the Axis powers divided Slovenian territory between them. In accordance with Hitler's directives, the largest parts of the territory were annexed by Hitler and Mussolini. The Kočevje region was administered by Italy. Gottscheers were offered the option to leave their homes and move to the German Reich. This relocation was not an isolated case, but part of Hitler's grand plan to unite all Germans within the territory of the Reich. Most of the population-11,509 people (Ferenc 2002: 155)—decided to relocate to the resettlement area. 
the most part. Nowadays, the Kočevje region is known especially for its primeval forests listed under UNESCO protection and large carnivores, especially the brown bear. Due to tragic historical events and the traumatic collective memory, the former inhabitants' rich cultural heritage nearly disappeared, whereas on the other hand some of the elements of intangible cultural heritage including folk songs were (and still are) dispersed all around the world (Moric 2016a).

Due to immigration from other places (see above) where different languages and dialects were spoken, as well as contacts with the surrounding population, it is not surprising that a mixed linguistic area developed in the Kočevje region. Indeed, the Gottscheer dialect borrowed some Slovenian words (Hauffen 1895; Schröer 1869; Tschinkel 2004) and therefore reflects the multilingualism of the area. The nationalist ideas that spread throughout Europe in the nineteenth and twentieth centuries were not open to such diversity; rather than focusing on similarities, they highlighted the differences and boundaries between ethnic groups (Barth 1998). Scholarly disciplines also played a role in emphasizing national characteristics (Weber-Kellermann 1959). In particular, folklore and linguistics were useful tools for any ideologically motivated collectors of cultural goods.

\section{THE BIRTH OF THE GOTTSCHEER "GERMAN LINGUISTIC ISLAND" AND COLLECTION OF FOLK SONGS}

Researchers started to look into the Kočevje area, including the Gottscheer folk songs and dialect, in the nineteenth century, beginning with Jožef Rudež (1793-1846), who in 1823 published the first dialect samples as well as texts of four Gottscheer songs in the periodical Vorzeit und Gegenwart. Soon after this publication, in the 1830s, ethnography of "linguistic islands" (Germ. Sprachinselvolkskunde) began in earnest. As is evident from the term "linguistic island" itself, this concept privileged language as a criterion of utmost significance for identifying a research subject, even though such research also included historical, cultural, and ethnic characteristics:

Because of their remoteness, the "islands" located outside the closed German language area were observed and approached as areas of linguistic and cultural relics ... . This increasingly became part of the national discourse and, in the context of socially widespread criticism of the new state order in Central Europe after the First World War and the resulting political revision requests, included a duty of care for Germans living outside the German state. (Heinke 2015)

In line with this concern for the existence of "endangered German linguistic islands," the collection of cultural goods picked up speed in the Kočevje area as well. Researchers, 
enlightened by Herderian ${ }^{8}$ romantic nationalism, went looking for elements of the ancient Germanic soul. Gottscheer culture and its past, customs, and so forth became a subject of academic interest. The "Gottscheer linguistic island," as part of the German nation, was "defined in a scholarly fashion according to the individual features that distinguished it from other groups" (Hroch 2007: 9) and pointed to its Germanness. The situation was best described by the author of the first dictionary of the Gottscheer dialect, Karl Julius Schröer, ${ }^{9}$ who wrote in 1891 that the Gottscheer:

Germanic people [...] retain the best qualities of the German essence and [are] especially attractive because of the old-fashioned features that were preserved in seclusion. That is, for their language, their habits and manners, and especially tales and songs that profess a deep and sincere folk-soul. (Schröer 1891: 418)

At the turn of the century the researchers exploring these "linguistic islands" were mostly scholars, teachers, and other intellectuals from German-speaking lands that came to the Kočevje region for research or work. They are the ones that assigned German origin to the Gottscheers, based on the linguistic similarity (see e.g., Schroer 1870; Haufen 1895), and gave them the denomination "Gottschee German” (e.g., Schroer 1869; Czoernig 1878). The collected folk tradition, including folk songs that were also printed as separate publications or in newspapers (cf. Anderson 2007: 67), together with the establishment of German schools in bilingual villages supported by the German nationalist organization Deutscher Schulverein (German School Association) ${ }^{10}$ and other nationalist activities, became the basis for the emerging nationalism in the Kočevje area.

However, the desired German "essence" had not yet "awakened," or was not yet recognized by Gottscheers in the mid-nineteenth century (Hauffen 1895: 165), and

8 Johann Gottfried Herder "through the publication of folk songs of different nations formed a view of the role of the folk song in the understanding of the nation" (Klobčar 2010: 126), since, according to him, nations differed in their folk song tradition. He was the first to use the term "folk song" (Bohlman 2004: 42).

9 Schröer's article was part of the book series Die Österreichisch-ungarische Monarchie in Wort und Bild (The Austro-Hungarian Monarchy in Word and Picture), which was published in 1884-1902 in Vienna and Budapest. The book series was designed by Crown Prince Rudolf. The aim of the work was to present features of all nations of Austria-Hungary, and thus through diversity promote unity and love towards the empire (Slavec Gradišnik 2016: 16-17).

10 The Deutscher Schulverein was founded in Vienna in 1880. Its main task was to raise money for German schools in linguistically mixed areas (Judson 2006: 17) and thus "protect" the Germanness of these regions. In 1885 they were followed by Slovenian nationalists with the founding of the Družba svetega Cirila in Metoda (Society of St. Cyril and Methodius). Czechs, Italians, and Poles had already established similar organizations (Drobesch 1992: 188). Another German nationalist organization, Verein Südmark (Southern March Association), bought land in mixed-language regions and settled German colonists there. The first Schulverein organization was established in the city of Kočevje in 1881 (Hriber 1930: 216). 
so it needed a little push. Song collecting and singing were very important tools for spreading a national consciousness or identification (Pisk 2018) in the Kočevje area as well. An account of this is found in the work of Adolf Hauffen (1863-1930), ${ }^{11}$ author of the first systematic folklore and ethnology study of the Gottscheer "linguistic island," Die Deutsche Sprachinsel Gottschee (The Gottschee German Linguistic Island) of 1895, in which he also described a situation regarding national identification in nineteenthcentury Kočevje area. Thus, he wrote about patriotism and (non-)awareness of German descent: "Local patriotism had been quite foreign to the Gottscheers a few decades ago; the rural population was previously hardly aware of its affiliation with the German people" (Hauffen 1895: 165-166). He goes on to note the role of song in arousing national emotions:

Fortunately, all this has now changed, and after the awakening of joyous pride in their homeland and German descent, they also needed a special patriotic song. Every local patriotic trait is absent in their old folk song treasure, but a song written by Professor Obergföll in the manner of the German consecration songs filled this gap. (Hauffen 1895: 165-166)

\section{A GOTTSCHEER ANTHEM: "WATCH ON THE KOLPA"}

Hauffen was writing about the song "Wacht an der Kulpa" (Watch on the Kolpa), written in 1875 by Josef Obergföll (1853-1921), ${ }^{12}$ which soon thereafter became the Gottscheer anthem. Moreover, the song became so popular that it spread among the people: "This 'Gottscheer anthem' actually became a folk song. Even the simplest man knows it; everywhere where Gottscheers sit happily with one another in a happy heart or a highspirited mood, at home or abroad, they sing it" (Hauffen 1895: 166). The song aimed to foster the Gottscheer national-or, better, Germanic_-identity, which is evident from the song's lyrics. ${ }^{13}$

11 Austrian philologist Adolf Hauffen, Assistant Professor at the German University of Prague, born in Ljubljana (Perz 1930: 196; Kundegraber 1964: 144) researched Gottscheer traditions, especially folk songs.

12 Josef Obergföll was born in Lienz, Austria, and studied linguistic in Innsbruck. He moved to Kočevje in 1875, three years after the German Secondary School (Germ. Gymnasium) was established. He was a teacher and school councilor as well as the author of several articles about the local history (Braune 1922a: 17-19).

13 New stanzas were added to the song as needed; e.g., both Johann Stampfl, the "great Gottscheer benefactor," and the Gottscheer emigrants living in America received the honor of a dedicated stanza of their own. A third stanza was even adopted by the Transylvanian Saxons, who adapted it by replacing "French blood" in the first line with "Hungarian blood" (Hauffen 1895: 167). 
Wacht an der Kulpa

Wahlspruch:

Tief unten aus der Wendenmark,

Da schalt uns frohe Kunde:

Ein deutscher Volkstamm, kühn und stark,

Reicht euch die Hand zum Bunde!

1. Vom Rinsequell zum Kolpastrand

Soll unser Lied ertönen;

Hoch lebe das Gottscheerland,

Hoch seinen deutschen Söhnen!

2. Uralt ist unseres Stammes Ruhm,

Wie unserer Wälder Eichen;

Gott schirm dich, deutsches Herzogthum,

Steh fest, magst nimmer weichen!

3. Osmanenblut, Franzosenblut

Hat unser Land gefärbet,

Den unverdross'nen deutschen Muth,

Den haben wir ererbet.

4. Ob auch manch feiger Feindeswicht

Uns lästern mag und hassen,

Wir werden deutsche Sitte nicht

Und deutsche Art nicht lassen.

5. Drum, Bruder, schließet fest den Bund

Für unsre deutsche Sache!

Wir schwören es mit Hand und Mund,

$\mathrm{Zu}$ halten treue Wache!

6. Erhebet euch in voller Schar,

Ruft, dass es wiederhalle:

Hoch lebe Östreichs Doppelaar,

Hoch Habsburg! es erschalle.

7. Drum, Bruder, reicht die Hand zum Bund, Die Glässer füllt zum Rande,

Lasst schallen es von Mund zu Mund:

Hoch dem Gottscheerlande!

(Hauffen 1895: 166-167)
Watch on the Kolpa

Motto:

Deep down from the Windic March, Glad tidings can be heard:

A German tribe, bold and strong,

Join your hands in union!

1. From the Rinža source to the Kolpa banks, Our song should resound.

Long live the Gottscheerland,

Long live its German sons!

2. Ancient is our kinship's fame,

As are the oaks of our forests.

God shield you German Duchy,

Stand firm, never ever yield!

3. Ottoman blood, French blood

Has colored our land,

The persistent German courage

We have inherited.

4. Whether some cowardly petty enemy

May revile and hate us,

We never will forsake the German custom

And our German ways.

5. Therefore, brothers, firmly join in union

For our German cause!

We swear with our hands and mouths

To keep a faithful watch!

6. Rise in full ranks,

Call out in resounding echoes:

"Long live Austria's double eagle,

Long live Habsburg! can be heard.

7. Therefore, brothers, join hands in union Fill the glasses to the brim!

Let it sound from mouth to mouth:

"Long live Gottscheerland!"

The song was authored for a public call intended for the selection of a patriotic song. The initiator of the public call was Benedict Knapp (1824-1904) from Schwarz, Tyrol, Austria, the headmaster of the Kočevje Secondary School (Germ. Gymnasium). His aim was to encourage Gottscheer patriotism because he had noticed they had "many good qualities, 
but the enthusiastic loyalty to the tribe, as we know it in Tyrol, is only weakly present in them" (Braune 1922b: 34). Six people applied and Obergföll's song was selected (Braune 1922b: 35).

The song is written in a similar vein to the German nationalistic song "Die Wacht am Rhein" (Watch on the Rhine), written in 1840 by Max Schneckenburger. In 1870 "Watch on the Rhine" became a popular military song (March Tappan 1914: 249) and spread throughout all German-speaking parts of Austria-Hungary. The song is a "typical example of a nationalist music imposed from up to the bottom" (Zăloagă 2017: 273). It belongs among the "Rhine songs" (Germ. Rheinlieder), which promoted national emotions towards Germany in its relation to France (Hopkins Porter 1977). It was still popular during the First World War (Zăloagă 2017), even among the Gottscheers. On July 30th, 1914, the song was sung at a patriotic meeting organized by members of the Turnverein (Gymnastics Society) $)^{14}$ and Kočevje students. They also sang the "Gottscheer anthem". ${ }^{15}$ They accompanied the Gottscheers that had been mobilized by singing both songs as they went off to war, ${ }^{16}$ and both were also sung by Gottscheer reservists. ${ }^{17}$

\section{BILINGUALISM IN GOTTSCHEER FOLK SONG}

Zmaga Kumer, an expert on the Gottscheer folk song tradition, wrote that "influence always flows in both directions along ethnic lines, and one cannot successfully explore one tradition without knowing the other" (Kumer 1987: 253). In her unpublished study of Gottscheer folk songs, ${ }^{18}$ she analyzed many examples of the exchange of folk song tradition and substance between the Slovenian- and Gottscheerish-speaking populations. In addition

14 The Turnverein gymnastics movement was started in 1811 in Berlin by the Prussian Friedrich Ludwig Jahn. Their aim was to overthrow Napoleon and unify Germany. By the end of the nineteenth century, the movement spread throughout Austria-Hungary. With exercise combined with patriotic speeches and the singing of traditional songs, these gymnastics societies also "helped to reinforce the sentiments of German national solidarity within the movement and to propagate new ideological currents" (Cohen 2006: 144). The Gottscheer deutschen Turnverein (Gottschee German Gymnastics Society) was established in 1885 with the support of the Laibacher deutschen Turnverein from Ljubljana (Hriber 1930: 216). A similar national movement called Sokol (Czech for "Falcon"), founded in Prague in 1862 (Nolte 2005: 126), formed in Slavic-speaking countries.

15 Aus Stadt und Land. Gottschee. (Begeisterte patriotische Kundgebung.). Gottscheer Bote 1914, 11 (15): 116.

16 Allgemeine Mobilisierung - Rekrutenabschied. Gottscheer Bote 1914, 11 (15): 116.

17 Laibach. (Unsere Reservisten). Gottscheer Bote 1914, 11 (15): 121.

18 Unfortunately, the analysis that Zmaga Kumer prepared for the fourth edition of the collection Gottscheer Volkslieder (Gottschee Folk Songs) is lost. I am grateful to Rolf Brednich, Jürgen Dittmar, and their colleagues at the Albert-Ludwigs University Center for Popular Culture and Music in Freiburg for their kind help in searching for the manuscript. An incomplete version is kept by the Archdiocesan Archive Ljubljana (Zmaga Kumer Papers, NŠAL 623, šk. 13). 
to Kumer, other researchers also noted similarities between the Slovenian/Slavic and Gottscheer traditions (e.g., Schroer 1891; Hauffen 1895; Marolt 1939; Ruch 1982; Tschinkel 2004; Golež Kaučič 2018). Hauffen, as one of the early researchers of the "Gottscheer German linguistic island” (Hauffen 1895: 159-163), was looking for "a German soul” in the Kočevje area, but at the same time in his book he also admits that cultural elements had been transferred from Slovenian (or Slavic) to Gottscheer communities (Hauffen 1895: 159-163). He also recorded a bilingual song, "Drei Mädchen” (Three Girls), which was sung in German and Slovenian: it alternates between German and Slovenian line-by-line. This song is a rare witness (besides information from newspapers (e.g., Trdan 1999: 62), church reports (Jeglič 2015: 45, 116, 181-182), and personal recollections (Moric 2016b: 200) about the actual multilingualism in (parts of) the Kočevje area at the turn of the century.

\section{Drei Mädchen ${ }^{19}$}

1.

Es blühen drei Rosen im Garten,

Tri lepe rožice,

Es sind ja keine Rosen,

So lepe deklice.

2.

Die eine heißt Marianka,

Ta druga Micinka.

Die dritte hat keinen Namen, Je moja ljubica.

\section{Three Girls}

1.

There are three roses in the garden,

Three beautiful roses

They are no roses,

They are beautiful girls.

2.

The first one is called Marianka, The second Micinka.

The third one has no name,

She is my sweetheart.

As evident from the Volkslied in Österreich (Folk Song in Austria) project, at the beginning of the twentieth century Gottscheer folk songs were already perceived by both Austrian and Slovenian researchers as German, and thus not as part of Slovenian culture. When the imperial Ministry of Culture and Education in Vienna commissioned Austrian folk song collection, in 1906 Gottscheers established their own working committee, which was separate from the Slovenian one. The committee consisted of the aforementioned Adolf Hauffen, his student Hans Tschinkel (born in Svetli Potok [Germ. Lichtenbach], Kočevje region), the Gottscheer pharmacist Robert Braune (secretary), and Josef Obergföll (the author of the Gottscheer anthem, see above) as a representative of the Provincial Government of Carniola. In August 1906 Wilhelm Tschinkel, school headmaster in Borovec, and Josef Perz, school headmaster in Koprivnik, were appointed corresponding members of the committee (Kundegraber 1964: 144-145). Two years later, the working committee commenced preparations for printing the collected material, ${ }^{20}$

19 This bilingual song was also known in a similar form elsewhere; e.g., in 1976 it was recorded in Potschach (Sln. Potoče pri Brdu) in the Gail Valley (Sln. Ziljska dolina) in Austria (Kumer 1986: 223).

20 They collected 550 songs, 120 nursery/counting rhymes, and 120 riddles (Kundegraber 1964: 146). 
and collecting was completed by the end of 1911. This was the first completed collection in the project. Two-thirds of the folk songs were written in the Gottscheer dialect and the rest were written either in German or as mixed versions (Kundegraber 1964: 146). Completion and printing of the planned issue of the relevant Gottscheer songs was prevented by the beginning of the First World War (Brednich 1969: 10); however, publication had previously been delayed for several years because of disagreements over whether the songs should be written in Gottscheer dialect or translated into German (Kundegraber 1964: 146). In accordance with the practice that was established in the nineteenth century, folk songs in dialect were classified under national categories ${ }^{21}$ or into collections of folk songs such as German, Swedish, or Polish (Bohlman 2004: 27). Thus, the common practice among both Slovenian and German researchers was also that the collected songs were recorded in the collectors' languages. A tendency was that songs in German (collected in Slovenian territory) were excluded from the printed editions of collections of Slovenian folk songs, and songs in Slovenian (collected in Austria among Carinthian Slovenians) were not included in Austrian collections (cf. Kumer 1986: 11). In the first two decades of the twentieth century, the situation in areas within AustriaHungary where German-speaking populations lived was such that the Austrian and German scholars collected "German linguistic island" songs ${ }^{22}$ as proof of Germanness, seeking ancient Germanic elements within them. However, Slovenian scholars omitted them from collections because they considered them foreign. Still, a few bilingual songs (such as the example above) were collected as well.

If early researchers of the Kočevje region such as Hauffen recognized the influence of Slovenian language and folklore on Gottscheers, after the First World War when the Kočevje area become a part of the newly founded Kingdom of Yugoslavia things became more complicated. Slovenian Germans were not satisfied with their changed status. The situation was similar in other newly formed independent national states, where

members of the former ruling nations became national minorities [...] Yet they remained unwilling to accept the equality of language of the small, but now ruling, nations of, for example, Czechs, Romanians, Serbs, Croats, etc., and this made for potentially explosive situations at the threshold of the Second World War. (Hroch 1996: 39-40)

21 For more on how the Habsburg Empire contributed to the flourishing of nationalisms through classification of languages, see Stergar and Sheer 2018.

22 Folk songs from the Kočevje region have been studied by German scholars and were included, for example, in the German ballad edition Deutsche Volkslieder mit ihren Melodien, Vol. 1, of 1935 (Meier 1935). I would like to extend my thanks to Rolf Brednich for information provided about the German folk song collections. 
In the interwar period, research into the "German linguistic islands" intensified, ${ }^{23}$ supported by various institutes such as the Deutsche Ausland-Institut in Stuttgart (German Foreign Institute in Stuttgart) and the Verein/Volksbund für das Deutschtum im Ausland (Association for Germans Abroad).

Because of their number and diversity, but also because of the increasing political importance in the course of the cession of land and the resulting revision efforts after the First World War, "linguistic islands" played a special role in east-central, eastern, and southeastern Europe. (Heinke 2015)

After the First World War and the change of regime in the new Yugoslav state, the aims for national (language) differentiation between "Germans" and "Slovenians" in the Kočevje area were fostered even more. Singing, more than ever before, was marked with a political note and was used for political purposes: to demonstrate the Gottscheers' German identity.

Some Gottscheer leaders perceived singing in Slovenian as a threat to the Gottscheers' Germanness. Gottscheer politician and lawyer Hans Arko (1888-1953) saw it as problematic that the Gottscheer young men continued singing Slovenian songs in their home villages upon their return from Yugoslav military service. Because of this "unbearable condition" (i.e., the fact that Slavic songs were replacing German songs), in 1922 Arko initiated the establishment of the Gottscheer Gesangverein (Gottscheer Choral Society). ${ }^{24}$ Under the pretext of cultural activity, the society operated primarily politically (Arko n.d.). It held several singing events accompanied by "song lectures," which were in fact political speeches, thereby significantly contributing to the strengthening of the German character of the Kočevje region. In his memoirs, probably dating to 1941, Hans Arko ascribed the organization a major role in "protecting" the Gottscheers from assimilation: "Today I can say with a clear conscience that the society has fully achieved its intended goal and that in case this society had not been founded there would be no Gottscheers available to resettle today" (Arko n. d.).

Singing of Gottscheer songs was encouraged also by arranging old songs in Gottscheerish and German for singing in the Kočevje church in the 1930s. The Gottscheer intelligentsia emphasized the Gottscheers' special traits by writing new poems in the Gottscheer dialect that soon became popular and spread among the people. In 1939, twenty-three old and

23 In the 1930s, the results of such research into the Kočevje area were, e.g., Groethe's book Die Deutsche Sprachinsel Gottschee in Slowenien (The German Linguistic Island Gottschee in Slovenia; Groethe 1931) and Gustav Adolf Küppers-Sonnenberg's sound recordings of Gottscheer songs (Kunej 2018).

24 The first choral society in Kočevje, the Gottscheer deutsche Gesangverein (Gottschee German Choral Society) was established in 1905, when the Sängerriege (Choral Societies) separated from the Gottscheer deutschen Turnverein (Gottschee German Gymnastics Society). The organization ceased to exist during the First World War (Hriber 1930: 216-217). In 1922 the Gottschee Choral Society was informally founded in the city of Kočevje. It was officially founded a year later, in 1923. 
new Gottscheer songs were edited in a polyphonic set and published in a choral booklet by Engelbert Maurin, a music teacher from Nemška Loka (Germ. Unterdeutschau; Rom 1980: 136).

In 1925, forty years after it was written, the singing of the Gottscheer anthem "Watch on the Kolpa" was banned by the Yugoslav authorities. The reason for the ban was not the promotion of belonging to the German nation but rather its hostility towards a friend of the Yugoslavian state: the French nation (Grothe 1931: 191). Particularly problematic was the third stanza (see above) about the French bloodshed in the Gottscheer rebellion against the French during the time of the Illyrian Provinces.

\section{A NEW ANTHEM AND NEW FOLK SONGS}

Soon after the prohibition of singing "Watch on the Kolpa," a new Gottscheer anthem, "Neue Gottscheer Hymne" was written by Josef Erker (1873-1939), ${ }^{25}$ a priest from Mozelj (Erker 1926: 14). ${ }^{26}$ It was created at the initiative of the central Gottscheer newspaper Gottscheer Zeitung to write an anthem that would replace the banned one and would be "capable of vigorously awakening, nurturing, and sustaining our love of the homeland, our national consciousness, our sense of belonging, and our fatherland." ${ }^{27}$ The "New Gottscheer Anthem” was published in Gottscheer Zeitung and Gottscheer Kalender.

Neue Gottscheer Hymne

Ein neues Lied, ein altes Lied.

Das wollen wir heut' singen:

Wir sind vom deutschen Volk ein Glied,

Hoch soll's an uns erklingen.

Uralt ist der Gottscheer Stamm.

Die Heimat sich zu bauen,

Der Väter Schar gezogen kam

Aus Deutschlands schönen Gauen.

Sie rodeten das wilde Land

Und jagten Wolf und Bären.

Den deutschen Mut, die starke Hand

Stets mußten sie bewähren.
New Gottscheer Anthem

A new song, an old song.

That's what we want to sing today:

We are a member of the German people,

Grand should it sound to us.

Ancient is the Gottscheer tribe.

Our home to build,

Our fathers' flock came drawn

From Germany's beautiful districts.

They cleared the wild land

And hunted wolves and bears.

The German courage, the strong hand

Always had to prove themselves.

25 Josef Erker served as a priest in Mozelj (Germ. Mösel) from 1901 to 1939. He regularly published articles about local history in the Gottscheer publications of the time.

26 In addition to its "Germanness," Erker also observed in Gottscheer folk song its moral and religious influence on the mind and inner life of the people.

27 Jahres-Rückschau. Gottscheer Kalender 1926, 6: 63. 
Im Glauben fest beharrten sie

In vieler Drangsal Mitte;

Von Gott beschützt, bewahrten sie

Die deutsche Art und Sitte.

So war es durch sechshundert Jahr',

Soll es nun anders werden?

O nein! Der liebe Gott bewahr'

Deutsch unsrer Heimat Erden!

Wir wollen gute Deutsche sein

Und keinen Slawen hassen.

Gottscheerland, die Heimat klein,

Muß mann uns Deutsch belassen!

Ihr Brüder, hebt die deutsche Hand.

Bekennt die deutsche Sache,

Bewahret das Gottscheer Land

In treuer, deutscher Wache!

(Erker 1926a: 14)
In faith, they firmly persisted

In the midst of many tribulations;

Protected by God, they preserved

The German style and custom.

So it was for six hundred years,

Should it be different now?

Oh no! Dear God preserves

Our German home soil!

We want to be good Germans

And not hate any Slavs.

Gottscheerland, our homeland small,

Must be allowed to remain German!

Brothers, raise the German hand.

Confess the German cause,

Preserve the Gottscheer land

In faithful, German guard!

On August 6th, 1926, the activities of the Gottscheer Choral Society were discontinued by the district administration because seventeen members of the association took part in a celebration in Carinthia (Rom 1980: 130), which demonstrated the German character of the Gottscheers. But the control and restrictions imposed by Yugoslav authorities did not stop the members, who decided that they would continue performing their political manifestations abroad, make annual trips to the Gottscheer villages, and increasingly teach songs in the Gottscheer dialect (Rom 1980: 130). The society was banned for four months. On November 30th, it continued "to maintain the German song with double zeal" (Hriber 1930: 218).

\section{FRANCE MAROLT VS. GOTTSCHEER ZEITUNG: GOTTSCHEER FOLK SONG OWNERSHIP BATTLE}

In 1930, Gustav Jungbauer (Weber-Kellerman 1959: 21) in his methodological guidelines for exploring "German linguistic islands" distinguished between the "old heritage" (Germ. Altgut) brought from the native country, the "new heritage" (Germ. Neugut) created on the territory of the island or taken from the local upper classes, and the "borrowed heritage" (Germ. Lehngut) taken from neighboring "linguistic islands" or the "foreign ethnic environment". Even at the end of the 1950s, researchers preferred to focus their attention on the "old heritage" (ibid.). Ingeborg Weber-Kellerman, a German ethnologist, in her critical reflection on exploring the "German linguistic islands," noted that researchers observed them as 
closed, well-defined living units and as parts of the German national body with a special peculiarity .... But here too, in addition to the joy of scholarly discovery, the national pride for the brave compatriots who have preserved German style and German meaning there on their "linguistic island" (i.e., in the midst of the hostile sea) often swings. And this feeling was nourished by the vocabulary of the "foreign ethnic environment," which is still part of the iron vocabulary of every folklorist who studies Germans abroad. (Weber-Kellermann 1959: 21)

Neither German nor Slovenian researchers avoided methodological nationalism (see Wimmer and Glick Schiller 2002). While German researchers were looking for Altgut, or ancient German elements in the Gottscheer songs (such as their origin in the Kudrun epic), Slovenian researchers were looking for Lehngut, or the Slovenian influence in them..$^{28}$ This even brought about a legal dispute between France Marolt, the first director of the Institute of Ethnomusicology, ${ }^{29}$ and the main Gottscheer newspaper the Gottscheer Zeitung. ${ }^{30}$ In 1937, the Slovenian nationalist organization Cyril and Methodius Society (Sln. Družba svetega Cirila in Metoda) opened a call for papers on the topic of Kočevje, to respond to German writings on the Gottscheer "German linguistic island," which had become particularly widespread following the celebration of the "600th Anniversary of Gottschee German settlement" in 1930. As a result of the project, in 1939 the Cyril and Methodius Society published the Kočevski zbornik (Gottschee Journal), in which Marolt's extensive paper "Slovenske prvine v kočevski ljudski pesmi" (Slovenian elements in Gottscheer folk song) was also published. Walter Hönigmann (1940: 1-2) criticized and mocked it in his article "Eine klare Antwort. Beruhen die musikalischen Behandlungen in Kočevski zbornik wirklich auf fachmännischen Kenntnissen?” (A clear answer. Are the musical treatments in Kočevski zbornik really based on expert knowledge?). Hönigmann denied that Marolt had any musicological knowledge and called him a dilettante. The reason for the attack was Marolt's claim that the Gottscheers received folk songs from the Slovenians. It is interesting that Hönigmann was a medical student, who himself did not know much about Gottscheer folk song and musicology. Although he claimed to be collecting Gottscheer folk songs, as noted by Zmaga Kumer (1991: 18), he was obviously not familiar with the collection of Hans Tschinkel created within the framework of the Folk Song in Austria project (see above), in which he attributed Slovenian origin to many songs or stated they

28 One of the oldest Gottscheer songs, "Die Meererin" (Sln. Primorka) tells a story about a lady by the sea. German researchers were looking for its origins as far back as the Kudrun epic (first Schröer, followed by others), whereas Slovenian researchers drew parallels with the Slovenian folk song "Lepa Vida" (Marolt 1939).

29 Known as the Folklore Institute before the Second World War.

30 In 1919 the Gottscheer Zeitung newspaper replaced its predecessor Gottscheer Bote. The Gottscheer Zeitung was published twice a month until the resettlement in 1941/42. In June 1955, the Gottscheer Landsmannschaft Klagenfurt (Gottscheer Association of Klagenfurt) began reissuing it. 
were created under Slovenian influence. Marolt himself, because of his own absorption with Slovenianness and his sense of it being threatened (by the Germans), "was unable to remain a sober, rational scholar," but rather "indiscriminately attacked 'Germanic scholarship' and reproached the German national writers" (Kumer 1991: 17) that their interests lay only in appropriation of cultural goods, as if this were not his goal as well. However, the dispute was the result of the political situation and the influence of national socialism in the Kočevje region at the beginning of the Second World War. It resulted in a lawsuit that Marolt (and the Minority Institute in Ljubljana) brought against the author of the article and the editor of the Gottscheer Zeitung. This story has never been resolved because of the resettlement of the Gottscheers, two years later, in 1941.

\section{NEW-OLD ANTHEM, NEW HOMELAND}

Hitler and Mussolini's troops invaded Yugoslavia on April 6th, 1941. According to Hitler's directives for the division of the Yugoslav territories, the Gottschee and Ljubljana Germans came under Italian rule (Ferenc 2002: 145). On August 31st, 1941, the treaty stipulated that German citizens and the Volksdeutscher ${ }^{31}$ (including the Gottscheers) should be allowed to relocate to the Reich. Despite the fact that many Gottscheers initially opposed the resettlement (Frensing 2012), as much as $95 \%$ of the population decided to move because of the (violent) propaganda spread by the young Nazi Gottscheer leadership. The Gottscheer agitators used various approaches to promote the resettlement to the Reich. In accordance with these new goals, the old Gottscheer anthem was modified accordingly:

Vom Rinsequell zum Kulpastrand

Hebt in den Wind die Fahnen,

Wir kehren heim ins Vaterland,

Die Heimat unsrer Ahnen.

Wir blieben deutsch trotz Haß und Not Trotz bittrer Knechtschaft Schande.

Es trieb das Osteraufgebot

Die Serben aus dem Lande.

Im Gleichschrittmarsch, der Trommel Schlag Gibt Schritt uns beim Marschieren.

Wir rufen in den jungen Tag:

Ein Volk, ein Reich, ein Führer!

(Lampeter 1941: 1)
From the Rinža source to the Kolpa banks

Raise the flags in the wind

We return to the homeland,

The home of our ancestors.

We remained German despite hatred and want In spite of the bitter shame of bondage. It drove the Eastern contingent

The Serbs out of the land.

In the forward march, the drumbeat

Gives us the step in the march.

We call in the young day:

One people, one empire, one leader!

31 This term was part of Nazi terminology and referred to the "ethnic Germans" living outside Germany, mostly in south and east European countries. 
During the interwar period, the newspapers Gottscheer Zeitung and Gottscheer Kalender regularly published local patriotic content, including poems in which they praised the quaint little region (Germ. Ländchen) and emphasized the importance of the Gottscheer dialect. After the occupation of Slovenian territory by German forces in 1941, when Nazism in the Kočevje region was at its peak, there was a noticeable "effort of the ethnic group leadership to reinterpret the concept of home to the Gottscheers; there was a sudden revaluation of the old picture of history, previous way of life, and even ideological basic convictions of National Socialist ethnic group thinking" (Frensing 1970).

If the first Gottscheer anthem promoted local patriotism, even if it simultaneously emphasized the German origin of the Gottscheers, and the second anthem promoted friendship with neighboring nations, the third brought a twist. The role of the Gottscheers' homeland is taken by Germany instead of the Kočevje region, and the song calls for the elimination of Serbs and joining with the Germans into a single land under Hitler: "One people, one empire, one leader!"

\section{FROM POLITICAL TO NOSTALGIC MEANS OF EXPRESSION: THE DIASPORA ANTHEM}

If the role of Gottscheer song in times before and during Second World War was political, it became nostalgic after the war, when Gottscheers were scattered around the world. The mass preservation of folklore traditions in migrant communities can be expressed in the singing of folk songs at or after mass community meetings (Žitnik 2005: 107). This is also the case with the Gottscheers in the diaspora. During my ethnographic fieldwork I visited several Gottscheers and participated in their events in Slovenia, Austria, the US, and Canada. I noticed that folk song is still a very important element of the Gottscheer tradition. For many Gottscheers it represents the last contact with their disappearing dialect, which is classified in the UNESCO Atlas of the World's Languages in Danger under "Critically Endangered Languages" due to its limited use (Mosley 2010). Only a few individuals speak the dialect in Slovenia, whereas the number of speakers in the US and Austria is slightly higher; but as the older generations of Gottscheers are dying out, the use of the dialect is rapidly declining (Moric 2010: 92-104; 2011: 22-27).

Singing is also important for preserving the memory of the old homeland, which is the basic element of the identity of the Gottscheers in the diaspora (see Moric 2018). As my interviewee Martha from New York put it: Singing connects people with language, land, and memories. It is almost sacred.

A song that was written around 1904 (Petschauer 1984: 91) by Wilhelm Tschinkel (1876-1938), an expatriate Gottscheer and a collector of Gottscheer folk tradition, became the Gottscheer anthem in the diaspora. The theme of the song is patriotic with no (direct) political inclination. 


\section{Der Gottscheerische Bub}

Du hast nur eine Mutter, einen Veter dazu, du hast nur eine Heimat, gottscheerischer Bub.

Draussen in der Welt gibt's Leute genug doch lieber daheim ist der gottscheerische Bub.

Die Gottscheer Leute sind alle so gut, sie sind alle wie Brüder, sie heben alle ein Blut.

Ein rechter Gottscheer, ob arm oder reich, er liebt seine Heimat g'rad wie das Himmelreich.

Gott Vater im Himmel, wir bitten gar schön, so lass uns die Heimat in Frieden bestehn. ${ }^{32}$
Gottscheer Lad (translation by John Tschinkel)

You have but one daddy, a mommy to add, You have but one homeland, Gottscheer lad.

Out in the world, many people are glad, But he prefers his home, this Gottscheer lad.

The Gottscheer folks, all brothers swell, All of one blood, all-loving and well.

A true Gottscheer, poor or rich, Loves his land and home, 'til he enters Heaven's dome.

God, Father in Heaven, we pray in the refrain, Let our little land in peace remain!

The song became a folk tune already before the Second World War. I noted that it is still sung at Gottscheer cultural events in Austria, the US, Canada, and Slovenia. Every year the biggest meeting of the Gottscheers in the US, the Gottscheer Volksfest in New York, begins with singing of the American anthem, which is followed by this song. This song in particular brings tears to the eyes of the elderly.

Gottscheer choirs, whose performances are always very emotional and nostalgic, are active in the US, Canada, and Austria. In addition to singing songs in Gottscheer dialect, the choirs also sing well-known German songs (e.g., "O Tannenbaum"). This is because the Gottscheers in the diaspora, besides their identification with the Kočevje area, also identify as Germans or Austrians, whereby the latter two identifications are conceived as the broader, general-category terms for their heritage (Thomason 2010: 27). Although they identify with the Kočevje region, their identity is not associated with the territory of the Republic of Slovenia or defined by its borders (Moric 2018: 10). The reason lies in the fact that prior to the Second World War when the Gottscheer community lived in the Kočevje area, Slovenia as an independent political formation did not exist, and thus they had no experience connected to it. On the other hand, the tragic historical events and traumas that affected Gottscheer collective memory prevent their identification with Slovenia (as a successor state of Yugoslavia; Moric 2016b: 189-202).

The performances of choirs singing Gottscheer folk songs are part of the ritual practices of the Gottscheers living in the diaspora: practically no (traditional) event will be organized without them. Gottscheers living in Slovenia do not have their own choir. However, after Slovenia became independent in 1991, the singing of Gottscheer songs was revived by Cantate Domino, a local choral society from the Kočevje region. The Gottscheer choirs 
from Europe and the US, as well as the Slovenian choir Cantate Domino, have issued several CDs with old Gottscheer songs.

In New York, there are two Gottscheer singers active. One of them, Werner Sommer, has released a CD of slightly updated Gottscheer folk songs, to which he has added a musical background, entitled Gottscheer Volkslieder (Gottschee Folk Songs). On his personal website, he wrote that he recorded the songs as a tribute to his Austrian heritage and to his mother, who was born in the Kočevje region. He remembers from his childhood how his relatives sat at a table after family celebrations and sang old songs. He always felt that he had to record these songs and thus rescue them from oblivion. ${ }^{33}$ The second singer, Hermann Stampfel (New York), is the only one who, in addition to keeping the old songs, also creates new ones in Gottscheerish. He wrote and compiled a collection of songs in the dialect. He chose Gottscheerish because it was always their family's conversational language. When he first fell in love in the 1970s, it seemed natural for him to express his emotions in the Gottscheer dialect. He says that in this manner he made a bow to the Gottscheer language.

It seems that even the troubles and discomfort of the past are forgotten through music. In the US I noticed that some of the older Gottscheers, who say that they cannot speak Slovenian, still know how to sing Slovenian folk songs that they had learned in Slovenia. Hilde from New York learned some of them before the Second World War in the Kočevje region, and some even after moving to New York through socializing with a relative's wife, who was Slovenian. Gustav from California learned Slovenian folk songs in Maribor, Slovenia, where his family resettled in 1941/42. On the other hand, there are Slovenian people living in the Kočevje area today that know how to sing Gottscheer songs. Slovenian folk songs can (occasionally) also be heard at events that are organized by Gottscheer organizations in Austria and the US. In 2015, a folk music ensemble performed a few Slovenian melodies (only music, without singing) at the Gottscheer Volksfest event in New York (e.g., "Trzinka" and "Mi se imamo radi" [We are fond of each other]), and Slovenian melodies can also be heard every year at a Sunday closing event at the Gottscheer Cultural Week (Germ. Gottscheer Kulturwoche) in Klagenfurt.

That puts a question mark on the common belief that the interaction between Slovenians and Germans in the Kočevje region before the Second World War was marked by incessant negativity or, on the other hand, was non-existent or defined (solely) by national battles. Paradoxically, it was the singing of songs, which were used for creating ethnic divides on many occasions, that actually (sometimes) also connected people of different nationalities_-or, better linguistic backgrounds—with each other.

33 Sommer, Werner. N .d. About. http://www.mkt.com/sommer-music/, accessed July 1, 2015. 


\section{CONCLUSION}

This case study of the Kočevje area indicates that national differentiation there followed a similar pattern to that in other mixed-language regions of Austria-Hungary (cf. Judson 2006). The collection of folklore material with the aim of proving the Germanness of the multilingual Kočevje area, as well as public calls for the selection of patriotic or pro-German songs, are examples of a patronizing attitude of the intelligentsia, in particular teachers, researchers, and students returning home, who came from major cities of the monarchy (Vienna, Prague, Graz, etc.) to the Kočevje region. These intellectuals, who were inspired with the German idea and felt a calling to defend Germanness and the German language against foreign (i.e., Slavic) influence (cf. Drobesch 1992: 190) helped to embed this concept of the national identity into the (mostly rural) local environment of the Kočevje area.

During the process of encouraging German consciousness, (folk) songs were also convenient. As evidenced by the versions of the Gottscheer anthem presented, the role of Gottscheer song varied in different political and social circumstances. Together with emphasizing the German character of the Gottscheers, the first Gottscheer anthem of 1875 also simultaneously encouraged local patriotism and love towards the Kočevje area. The second version from 1925, despite urging loyalty to Germanness, also promoted friendship among neighboring nations, which was pragmatic and in line with the changed status of the German-speaking minority in the Kingdom of Yugoslavia. At that time Gottscheers could only foster their German identity through cultural activities, which at the same time demonstrated their loyalty to the Yugoslav state. The third version, written in 1941 under the influence of Nazism, openly expressed hatred towards the Serbs and urged the Gottscheers to relocate to their "ancestral" homeland: the German Reich. This put the previously praised Kočevje region in the position of a temporary homeland: a step on the Gottscheers' path to reunite with their German homeland.

After the Second World War, when most Gottscheers became a diaspora, the tendency to preserve the memory of the Kočevje region, which is reflected in the final and also current Gottscheer anthem, came to the fore. The first place on the podium of homeland memory belongs to Kočevje, whereas Germany and Austria are at the same time considered as part of a wider Gottscheer identity. The Gottscheer song that became an important element of the identity of the Gottscheers in the diaspora is faced with another challenging task today: to preserve ties with the disappearing Gottscheer dialect.

The collection and interpretation of Gottscheer folk songs, especially during the interwar period, resulted in appropriation and one-sided interpretations (see the France Marolt-Gottscheer Zeitung dispute described above). The image of the prewar Kočevje region as a closed-off "German linguistic island" has been retained to this day with the help of scholarly disciplines such as linguistics, historiography, folkloristics, whereas its actual multilingualism has slipped into oblivion. However, the Gottscheer songs, whose subject matter was in many cases either common or passed from one linguistic group to another 
and that were sometimes multilingual, such as the case of "Three Girls" (recorded in 1895), remind us of the linguistic variety and long centuries of coexistence in the Kočevje area, as well as of the pitfalls and snares of scholarly research.

\section{REFERENCES}

Almasy, Karin, and Eva Tropper. 2018. Štajer-mark: 1890-1920: Der gemeinsamen Geschichte aufder Spur: Postkarten der historischen Untersteiermark = Štajer-mark: 1890-1920: Po sledeh skupnepreteklosti: Razglednice zgodovinske Spodnje Štajerske. Laafeld: Artikel-VII-Kulturverein für Steiermark - Pavelhaus.

Anderson, Benedict. 2007. Zamišljene skupnosti: O izvoru in širjenju nacionalizma. Ljubljana: Studia humanitatis.

Arko, Hans. N.d. Gedächtnisschrift, Dr. Hans Arko, Advokat in Gottschee, keine Datierung - wahrscheinlich Ende November 1941. http://www.gottschee.de/Dateien/Dokumente/Web\%20Deutsch/Arko/ Gedaechtnisschrift.htm (Accessed April 10, 2020).

Barth, Fredrik. 1998. Introduction. In: Fredrik Barth (ed.), Ethnic Groups and Boundaries: The Social Organization of Culture Difference. Illinois: Waveland Press, 9-38.

Bohlman, Philip V. 2004. The Music of European Nationalism: Cultural Identity and Modern History. Santa Barbara: ABC-CLIO, Inc.

Braune, Robert. 1922a. Schulrat Josef Obergföll. Gottscheer Kalender 2: 17-19.

Braune, Robert. 1922b. Wie das Gottscheer Heimatlied entstand. Gottscheer Kalender 2: 34-38.

Brednich, Rolf W., and Wolfgang Suppan. 1969. Gottscheer Volkslieder: Vol. I: Volksballaden. Mainz: B. Schott's Söhne.

Brednich, Rolf W., and Wolfgang Suppan. 1972. Gottscheer Volkslieder: Vol. II: Geistliche Lieder. Mainz: B. Schott's Söhne.

Brednich, Rolf W., and Wolfgang Suppan. 1984. Gottscheer Volkslieder: Vol. III: Weltliche Lieder, Volkstänze, Nachträge zu Band I. Mainz: B. Schott's Söhne.

Cohen, Gary B. 2006. The Politics of Ethnic Survival: Germans in Prague, 1861-1914. West Lafayette, Indiana: Purdue University Press.

Cvirn, Janez. 2002a. Nemško (avstrijsko) in slovensko zgodovinopisje o Nemcih na Slovenskem (1848-1941). In: Dušan Nećak (ed.), »Nemci« na Slovenskem 1941-1955. Ljubljana: Znanstveni inštitut Filozofske fakultete, 69-98.

Cvirn, Janez. 2002b. Nemci na Slovenskem (1848-1941). In: Dušan Nećak (ed.), »Nemci« na Slovenskem 1941-1955. Ljubljana: Znanstveni inštitut Filozofske fakultete, 99-144.

Czoernig, Karl. 1878. Die Deutsche Sprachinsel Gottschee: Mit einer ethnographischen Karte: vortrag, gehalten in der Section Küstenland des Deutschen und Österreichischen Alpenvereins am 23. November 1878. Munich: n.p.

Čuček, Filip, and Janez Cvirn. 2012. Uvod. In: Jerneja Ferlež (ed.), Nemci in Maribor: Stoletje preobratov 1846-1946. Maribor: Umetniški kabinet Primož Pemzl, 30-32.

Drnovšek, Marjan. 2005. Izseljevanje Kočevarjev v Združene države Amerike. Dve domovini 21: 7-34.

Drobesch, Werner. 1992. Deutscher Schulverein: Njegova ideologija, notranja struktura in delovanje $s$ posebnim ozirom na Slovenijo. Zgodovinski caasopis 46 (2): 187-198. 
Erker, Josef. 1926. Neue Gottscheer Hymne. Gottscheer Kalender 6: 14.

Falzon, Mark-Anthony. 2009. Introduction. In: Mark-Anthony Falzon (ed.), Multi-Sited Ethnography: Theory, Praxis and Locality in Contemporary Research. Surrey and Burlington: Ashgate, 1-24.

Ferenc, Mitja. 2005. Kočevska - pusta in prazna: Nemško jezikovno območje na Kočevskem po odselitvi Nemcev. Ljubljana: Modrijan.

Ferenc, Mitja, and Božo Repe. 2004. Nemška manjšina v Sloveniji med obema vojnama. In: Dušan Nećak et al. (eds.), Slovensko-avstrijski odnosi v 20. stoletju. Ljubljana: Oddelek za zgodovino Filozofske fakultete, $147-160$.

Ferenc, Tone. 2002. Nemci na Slovenskem med drugo svetovno vojno. In: Dušan Nećak (ed.), »Nemci« na Slovenskem 1941-1955. Ljubljana: Znanstveni inštitut Filozofske fakultete, 145-190.

Frensing, Hans Hermann. 1970. Die Umsiedlung der Gottscheer Deutschen: Das Ende einer südostdeutscher Volksgruppe. Munich: Verlag R. Oldenbourg. http://www.gottschee.de/Frames/Mainframe/Deutsch/ Umsiedlung.htm, accessed January 12, 2020.

Frensing, Hans Hermann. 2012. Public lecture about the Gottscheer resettlement, September 25. Kočevje: Pokrajinski muzej Kočevje.

Golež Kaučič, Marjetka. 2018. Slovenska ljudska balada. Ljubljana: Založba ZRC.

Gottscheer Chöre. 1980. Gottscheer Liederheft: Herausgegeben von den Gottscheer Chören anlässlich der Gottscheer 650 - Jahrfeier in Ridgewood, New York, U.S.A. New York: Gottscheer Chöre.

Grothe, Hugo. 1931. Die deutsche Sprachinsel Gottschee in Slowenien: Ein Beitrag zur Deutschtumskunde des europäischen Südostens. Münster: Aschendorffsche Verlagsbuchhandlung.

Hauffen, Adolf. 1895. Die Deutsche Sprachinsel Gottschee: Geschichte und Mundart, Lebensverhältnisse, Sitten und Gebraüche, Sagen, Märchen und Lieder. Graz: K.K. Universitäts-Buchdruckerei und Verlags-Buchhandlung "Styria."

Heinke, M. Kalinke. 2015. Sprachinselforschung. In: Online-Lexikon zur Kultur und Geschichte der Deutschen im östlichen Europa. https://ome-lexikon.uni-oldenburg.de/p32772, accessed January 7, 2020.

Hobsbawm, Eric J. 2007. Nacije in nacionalizem po letu 1780: Program, mit in resničnost. Ljubljana: ${ }^{*} \mathrm{Cf}$.

Hopkins Porter, Cecilia. 1977. The "Rheinlieder" Critics: A Case of Musical Nationalism. The Musical Quarterly 63: 74-98.

Hönigmann, Walter. 1940. Eine klare Antwort: Beruhen die musikalischen Behandlungen in Kočevski zbornik wirklich auf fachmännischen Kenntnissen? Gottscheer Zeitung 37 (5): 1-2.

Hriber, Franz. 1930. Die Vereinswesen in Gottschee. In: JosefErker (ed.), Jubiläums-Festbuch der Gottscheer 600-Jahresfeier: Aus Anlaß des 600-jährigen Bestandes des Gottscheer Landes. Kočevje: Festausschuss der Gottscheer 600-Jahrfeier, 215-219.

Hroch, Miroslav. 1996. Nationalism and National Movements: Comparing the Past and the Present of Central and Eastern Europe. Nations and Nationalism 2 (1): 35-44.

Hroch, Miroslav. 2007. National Romanticizm. In: Balazs Trencsenyi and Michal Kopecek (eds.), Discourses of Collective Identity in Central and Southeast Europe 1770-1945. Budapest: Central European University Press, 4-18.

Jeglič, Anton Bonaventura. 2015. Jegličev dnevnik: Znanstvenokritična izdaja. Celje: Celjska Mohorjeva družba.

Judson, Pieter M. 2006. Guardians of the Nation: Activists on the Language Frontiers of Imperial Austria. Cambridge, MA: Harvard University Press.

Judson, Pieter M. 2018 (2016). Habsburški imperij: Nova zgodovina. Ljubljana: Sophia. 
Klobčar, Marija. 2010. Zvrstnost slovenskih ljudskih pesmi. Traditiones 39 (2): 125-147. DOI: https:// doi-org/10.3986/traditio2010390208.

Komac, Miran, and Dean Zagorac. 2002. Varstvo manjšin: Uvodna pojasnila \& dokumenti. Ljubljana: Društvo Amnesty International Slovenije in Inštitut za narodnostna vprašanja.

Kosi, Jernej. 2010. Je bil proces formiranja slovenskega naroda v 19. stoletju res zgolj končni nasledek tisočletne slovenske kontinuitete? Zgodovinski časopis 64 (1-2): 154-175.

Kumer, Zmaga. 1986. Slovenske ljudske pesmi Koroške: Vol. II: Ziljska dolina. Trst: Založništvo tržaškega tiska; Klagenfurt: Drava.

Kumer, Zmaga. 1987. Lepá vodá Ljubljánčicá. Traditiones 16: 247-254.

Kumer, Zmaga. 1991. France Marolt (1891-1951) (Ob stoletnici rojstva slovenskega etnomuzikologa). Traditiones 20: 9-28.

Kundegraber, Maria. 1964. Das Schicksal der Gottscheer Volksliedsammlung (1906-1912). Sonderdruck aus dem Jahrbuch des Österreichischen Volksliedwerkes 13: 143-148.

Kunej, Drago. 2018. Posnetki slovenskih pesmi v berlinskem Phonogramm-Archivu kot primer Drugega. Glasnik Slovenskega etnološkega društva 58 (1-2): 17-26.

Lampeter, Wilhelm. 1941. Wir wollen heim ins Reich! Gottscheer Zeitung 38 (29): 1.

Lobe, Bojana. 2006. Združevanje kvalitativnih in kvantitativnih metod - stara praksa v novi preobleki? Družboslovne razprave 22 (53): 55-73.

March Tappan, Eva. 1914, The World's Story: A History of the World in Story, Song and Art. Vol. 7: Germany, The Netherlands, and Switzerland. Boston: Houghton Mifflin.

Marcus, George E. 1995. Ethnography in/of the World System: The Emergence of Multi-Sited Ethnography. Annual Review of Anthropology 24: 95-117.

Marolt, France. 1939. Slovenske prvine v kočevski ljudski pesmi. In: Janko Mačkovšek (ed.), Kočevski zbornik: Razprave o Kočevski in njenih ljudeh. Ljubljana: Vodstvo Družbe sv. Cirila in Metoda, 175-320.

Meier, John. 1930. Gottscheer Volkslieder mit Bildern und Weisen. Berlin: W. de Gruyter.

Meier, John et. al. 1935. Deutsche Volkslieder mit ibren Melodien. Berlin: W. de Gruyter.

Moric, Anja. 2010. Ohranjanje kočevarščine, narečja kočevskih Nemcev, v Sloveniji, Avstriji, Nemčiji, Kanadi in ZDA. Razprave in gradivo - Inštitut za narodnostna vprašanja 61: 92-119.

Moric, Anja. 2011. The Maintenance of Gottscheerisch, the Dialect of Gottschee Germans in Slovenia, Austria, Germany, Canada and the USA. Europa Ethnica: Nationalitätenfragen: = Questions ethnique $=$ Problems of Nationalities 68 (1/2): 21-31.

Moric, Anja. 2016a. Nesnovna kulturna dediščina kočevskih Nemcev: Včeraj in danes, med staro in novimi domovinami. In: Rok Andres et al. (eds.), Mednarodno znanstveno srečanje mladih humanistov: Slovanski jeziki na stičišču kultur, Konferenčni e-zbornik. Ljubljana: Zveza društev Slavistično društvo Slovenije (Študentska sekcija), 103-116.

Moric, Anja. 2016b. Slovenski Nemci v diaspori. Unpublished doctoral dissertation. Ljubljana: Faculty of Social Sciences, University of Ljubljana.

Moric, Anja. 2018. Territorial Identifications of the Gottschee Germans: Diaspora - Homeland Relation. Motus in verbo 7 (1): 7-21.

Mosley, Christopher (ed.). 2010. Atlas of the World's Languages in Danger. 3rd ed. Paris: UNESCO Publishing. http://www.unesco.org/languages-atlas/en/atlasmap.html, accessed April 15, 2020. 
Nolte, Claire E. 2005. All for One! One for All! The Federation of Slavic Sokols and the Failure of NeoSlavism. In: Pieter M. Judson and Marsha L. Rozenblit (eds.), Constructing Nationalities in East Central Europe. New York: Berghahn, 126-140.

Perz, Josef. 1930. Das Gottscheer Volkslied. In: Josef Erker (ed.), Jubiläums-Festbuch der Gottscheer 600-Jahresfeier: Aus Anlaß des 600-jährigen Bestandes des Gottscheer Landes. Kočevje: Festausschuss der Gottscheer 600-Jahrfeier, 195-198.

Petschauer, Erich. 1984. Das Jahrhunderbuch: Gottschee and Its People through the Centuries. New York: Gottscheer Relief Association.

Pisk, Marjeta. 2018. Vi čuvarji ste obmejni: Pesemska ustvarjalnost Goriških brd v procesih nacionalizacije kulture. Ljubljana: Založba ZRC, ZRC SAZU.

Rom, Konrad. 1980.Zur Gottscheer Vereinsgeschichte. In: Ludwig Kren (ed.), 650 Jahre Gottschee Festbuch 1980. Klagenfurt: Gottscheer Landsmannschaft in Klagenfurt, 129-142.

Ruch, Martin. 1982. Die Gottschee als Volksliedlandschaft.Jahrbuch Für Volksliedforschung 27/28: 175-185.

Schröer, Karl Julius. 1869. Ein Ausflug nach Gottschee: Beitrag der Erforschung der Gottscheer Mundart. Vienna: K. K. Hof- und Staatsdrückerei.

Schröer, Karl Julius. 1870. Wörterbuch der Mundart von Gottschee von Karl Julius Schröer: Vol. I: Ausflug nach Gottschee; Vol. II: Weitere Mitheilungen über die Mundart von Gottschee. Vienna: Hof-U. Staatsdruckerei.

Schröer, Karl Julius. 1891. Die österreichisch-ungarische Monarchie in Wort und Bild: Kärnten und Krain. Vienna: K. K. Hof- und Staatsdruckerei, Alfred von Hölder.

Slavec Gradišnik, Ingrid. 2016. Avstro-ogrska monarhija v besedi in podobi. In: Monika Kropej Telban and Ingrid Slavec Gradišnik (eds.), Avstro-ogrska monarhija v besedi in podobi - Slovenci 1: Štajerska, Porabje in Prekmurje, Koroška. Ljubljana: Založba ZRC, ZRC SAZU, 7-25.

Stanonik, Marija. 2004. Kočevarska slovstvena folklora: Primerjava in slovenske vzporednice. In: Alojzij Pavel Florjančič and Marija Stanonik (eds.), Kočevarska folklora: V šegah, navadah, pravljicah, povedkah, legendah in drugih folklornih izrocilih = Gottscheer Volkstum: In Sitte, Brauch, Märchen, Sagen, Legenden und anderen volkstümlichen Überlieferungen by Wilhelm Tschinkel. Ljubljana: Založba ZRC, 229-280.

Stergar, Rok, and Tamara Sheer. 2018. Ethnic Boxes: The Unintended Consequences of Habsburg Bureaucratic Classification. Nationalities Papers 46 (4): 575-591.

Sweers, Britta. 2005. The Power to Influence Minds: German Folk Music during the Nazi Era and After. In: Annie J. Randall (ed.), Music, Power, and Politics. New York: Routledge, 65-86.

Thomason, Bobbi. 2010. Memories of Gottschee: A Narrated History of Fidelity and Fragility. CreateSpace Independent Publishing Platform.

Trdan, Vanda. 1999. Življenje kočevskih Nemcev med 1850 in 1918. Master's thesis. Ljubljana: Faculty of Social Sciences, University of Ljubljana.

Tschinkel, Wilhelm. 2004. Kočevarska folklora: V̌̌egah, navadah, pravljicah, povedkah, legendah in drugih folklornih izročilih = Gottscheer Volkstum: In Sitte, Brauch, Märchen, Sagen, Legenden und anderen volkstümlichen Überlieferungen. Ljubljana: Založba ZRC, ZRC SAZU.

Weber-Kellermann, Ingeborg. 1959.Zur Frage der interethnischen Beziehungen in der "Sprachinselvolkskunde." Österreichische Zeitschrift für Volkskunde 13 (62): 19-47.

Wimmer, Andreas, and Nina Glick Schiller. 2002. Methodological Nationalism and Beyond: Nation-State Building, Migration and the Social Sciences. Global Networks 2 (4): 301-334. 
Zăloagă, Marian. 2017. The Musical Arsenal in the First World War: "Die Wacht am Rhein” in Transylvanian Saxons' Repertoire. In: Irina Vainovski-Mihai (ed.), New Europe College Ştefan Odobleja Program Yearbook 2017-2018 Bucharest: New Europe College, 271-297.

Žitnik, Janja. 2005. Kulturno življenje v izseljenstvu: Koncept kompleksne obravnave. Dve domovini 21: $105-124$

\section{KOČEVARSKA (LJUDSKA) PESEM - OD ORODJA ZA SPODBUJANJE NACIONALNE DIFERENCIACIJE DO VARUHINJE SPOMINA V DIASPORI}

Prispevek se posveča rabi kočevarske ljudske pesmi za identifikacije Kočevarjev od srede 19. stoletja do danes. S tem prispeva $k$ a) razjasnitvi še neraziskanega procesa ustvarjanja nacionalnih identitet na Kočevskem in b) ponudi vpogled v sedanjost Kočevarjev v diaspori.

$V$ prvem delu na podlagi analize zbirk kočevarskih pesmi in arhivskih virov kritično premisli proces nacionalizacije kočevarske ljudske pesmi od 19. stoletja do preselitve Kočevarjev v letih 1941/42. Pokaže, kako jev 70. letih 19. stoletja pesem postala orodje nacionalističnih aktivistov, zlasti izobražencev iz avstro-ogrskih mest, za vzbujanje pripadnosti nemštvu na "ogroženem" kočevskem "jezikovnem otoku«. Tedaj so po vzoru nacionalističnih nemških pesmi nastajale nove, pronemške pesmi, ki so z leti ponarodele. Spreminjanje vloge kočevarske pesmi v različnih politično družbenih okoliščinah je v članku ponazorjeno z analizo štirih različic kočevarske himne. Prva himna (1875) je sočasno poudarjala nemški značaj Kočevarjev in spodbujala njihov lokalni patriotizem. Druga (1925) je v skladu s spremenjenim statusom nemško govoreče manjšine v Jugoslaviji pozivala k zvestobi nemštvu in hkrati pragmatično spodbujala prijateljstvo s sosednjimi narodi. Tretja, napisana pod vplivom nacizma (1941), pa je odkrito izražala sovraštvo do Srbov in z nagovarjanjem Kočevarjev k preselitvi v nemški rajh rekonceptualizirala pojem domovine. Avtorica na podlagi svoje raziskave med Kočevarji v Sloveniji, Avstriji, Nemčiji, ZDA in Kanadi $v$ drugem delu prikaže, kako se je z novo družbeno realnostjo, v kateri so se po 2. svetovni vojni znašli kočevarski izseljenci, spremenila vloga kočevarske ljudske pesmi. Vospredje je stopila težnja po ohranjanju spomina na domovino Kočevsko, ki se med drugim izraža v zadnji, današnji, kočevarski himni. Kočevarska pesem, ki je sestavni del identitete Kočevarjev (v diaspori), ima danes še eno zahtevno nalogo - ohranjati vez z izginjajočim kočevarskim narečjem.

Članek se dotakne tudi prisvajanja in enostranskih interpretacij, do katerih je pri zbiranju in analizi kočevarskih ljudskih pesmi prihajalo zlastiv času pred 2. svetovno vojno (in privedlo do spora med Francetom Maroltom in časopisom Gottscheer Zeitung). Podoba predvojne Kočevske kot zaprtega "nemškega jezikovnega otoka, "ki so jo ustvarili z nemško idejo navdahnjeni raziskovalci, se je s pomočjo znanstvenih ved, zlasti lingvistike, zgodovinopisja in folkloristike, obdržala vse do danes. Prispevek opozori na to, da prav kočevarske pesmi s snovjo, ki je bila skupna oz. je prehajala od ene jezikovne skupnosti k drugi, kot tudi z večjezičnostjo, kakršno najdemo v pesmi "Tri deklice", pričajo o jezikovni raznovrstnosti in stoletnem sobivanju na Kočevskem, kot tudi o pasteh in zankah znanstvenega raziskovanja. 
Dr. Anja Moric, Research Assistant

University of Ljubljana, Faculty of Arts, Department od

Ethnology and Cultural Anthropology

Aškerčeva 2, SI - Ljubljana, Slovenia

and

ZRC SAZU, Institute of Ethnomusicology

Novi trg 2, SI - 1000 Ljubljana, Slovenia, anja.moric@zrc-sazu.si

The article was written as part of the project Song Reflections on Intercultural Coexistence (J6-9369) and the core funding research program No. P6-0187 (Slovene Identities in the Context of the European Space), financed by Slovenian Research Agency. For their helpful feedback, I thank Eric Dickson from the New York University and my colleagues at the Institute for Ethnomusicology ZRC SAZU as well as the anonymous reviewers. 